\title{
Konfüzyon ve halüsinasyon ile prezente olan olası primer santral sinir sistemi vasküliti: bir olgu
}

\section{Possibleprimary central nervous system vasculitis presentıng with confusion and hallucination: a case}

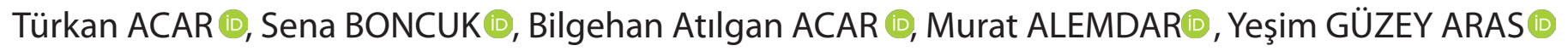

Sakarya Üniversitesi Eğitim ve Araştırma Hastanesi, Nöroloji AD, Sakarya/TÜRKIYE

\section{Öz}

Primer santral sinir sistemi vasküliti (PSSSV), sistemik vaskülit belirtisi olmadan beyin ve omurilikteki damarlarının nadir bir inflamatuar hastalığıdır. Tanı zorluğu nedeniyle tam insidansını belirlemek zordur. Klinik geniş nörodefisitler içerebildiği gibi subakut-kronik seyirlidir. Kesin tanı için önerilen biyopsi veya serebral anjiografinin beklendiği kadar yüksek özgüllüğü yoktur. Prodromal bir kliniğin bulunması, nörodefisit varlığı, sistemik bulguların ekartasyonu, MRG'de atipik lezyonların varlığı, anormal BOS analizi ile de olası PSSSV tanısına ulaşılabilir. Tedavide steroid ve siklofosfamid gibi immunsüpresif ajanlar kullanılmaktadır. Bu yazıda anormal BOS bulgularının olduğu ve MR spectroskopiden faydalanılarak olası PSSSV tanısı alan olgu sunulmuştur.

Anahtar kelimeler: vaskülit; konfüzyon; santral sinir sistemi

\section{Abstract}

Primary central nervous system vasculitis (PCNSV) is a rare inflammatory disease of the vessels of the brain and spinal cord without signs of systemic vasculitis. Due to the difficulty of diagnosis, it is difficult to determine the exact incidence. Clinical findings may include a wide variety of neurodeficides and are subacute-chronic. The biopsy or cerebral angiography recommended for definitive diagnosis does not have as high specificity as expected. The presence of a prodromal clinic, the presence of neurodeficitis, the elimination of systemic findings, the presence of atypical lesions on MRI, and abnormal CSF analysis can also lead to a diagnosis of PSSSV. Immunosuppressive agents such as steroids and cyclophosphamide are used in the treatment. In this article, we present a case with abnormal CSF findings and a diagnosis of possible PSSSV using MR spectroscopy.

Keywords: vasculitis; confusion; central nervous system

Sorumlu Yazar*: Türkan Acar, Sakarya Üniversitesi Eğitim ve Araştırma Hastanesi, Nöroloji AD, Sakarya/TÜRKiYE E-posta: tdeniz38@hotmail.com

Gönderim:09.01.2020 Kabul: 09.03.2020

ORCID: 0000-0003-2001-914X

Doi: $10.18663 / \mathrm{tjcl} .672580$ 


\section{Giriş}

Primer santral sinir sistemi vasküliti (PSSSV), sistemik vaskülit belirtisi olmadan beyin ve omurilikteki damarlarının nadir bir inflamatuar hastalığıdır. PSSSV ilk olarak 1959'da ayrı bir klinik antite olarak tanımlanmış olup farklı klinik vakalar bildirilmiştir (1). Hastalığın literatürde bildirilen insidansı 2,4/milyon'dur (2). Bildirilen vaka sayısının az olmasının bir sebebi de tanı koymak için net bir tanı testinin bulunmamasıdır.

Histopatolojik tanı varlığında bile sistemik eşlik eden vaskülit olmadığı gösterilmelidir. Klinik, laboratuvar ve radyolojik bulgularla tanı desteklenmelidir (3). Birçok klinik prezentasyonla başvuru olsa da en sık görülen semptom baş ağrısıdır. Diğer semptomlar arasında hemiparezi, afazi, uyuşukluk, görsel semptomlar, ataksi gibi fokal nörolojik bozukluklar bulunur (1,4-7).

Kesin tanı için serebral anjiografive biyopsinin gerekliliği mutlak olarak belirtilse de sınırlamaları olduğunu belirten yayınlar da mevcuttur.Bu yayınlarda manyetik rezonans görüntüleme (MRG) ve anjiografi bulguları ile birlikte uyumlu bir BOS profili varsa biyopsiye gerek olmadan yüksek olasılıkla PSSSV tanısı konulabileceği belirtilmektedir(8).

Bu yazıda, sağ alt ekstremitede ilerleyici güçsüzlük ve konfüzyon ile tarafımıza başvuran ve epileptik nöbeti olan, manyetik rezonans görüntüleme (MRG), MR anjiografi ve beyin omurilik sıvısı (BOS) analiz sonuçlarına göre olası PSSSV tanısı alan 64 yaşındaki kadın olgu irdelenmiştir.

\section{Olgu}

64 yaş kadın hasta sağ bacakta güçsüzlük, şuurda bozulma, anlamsız hareketler şikayeti ile nöroloji polikliniğine başvurdu. Şikayetleri 2 ay önce başlamış ve bu süreçte ilerlemiş. Kliniğine yatışında her iki alt ekstremitede güçsüzlük, denge kaybı ve konuşmada zorlanma, endişe ve korku hali mevcuttu. Ara ara halüsinasyon ve ajitasyon eşlik ediyordu. Öyküsünde bilinen diabetes mellitus dışında hastalığı yoktu. Nörolojik muayenesindebilinçkonfüze, yer vezaman oryantasyonu bozuk, pupiller izokorik ışık refleksi +/+, ekstraoküler göz hareketleri serbest, sağ nazolabial oluk silik, sağ üst ekstemite 4/5, sağ alt ekstremite $3 / 5$ kas gücünde, sol üst ekstremite kas gücü tam, sol alt ekstremite 4/5 kas gücünde idi. Hastanın çekilen kranial MRG'sinde sol parietal, sol frontal ve sağ parietooksipitalde 5-6 adet T2 ağırlıklı kesitlerde hiperintens görülen lezyon izlenmesi üzerine hasta ileri inceleme amaçlı nöroloji kliniğine yatırıldı (Şekil 1). Yatış sonrasında hastanın jeneralize tonik klonik nöbeti izlendi ve hastaya levetirasetam başlandı.Rutin biyokimya, hemogram tahlilleri ve vital bulgularında patolojik bulgu saptanmadı. Hastanın yapılan BOS analizindehücre saptanmadı, mikroprotein 84,5 mg/dl, glukoz 74 mg/dl idi. Bos sitolojisinde hücresel eleman saptanmadı. Hastanın hepatit, HIV, VDRL, TORCH, brusella antikor sonuçları negatif saptandı. Vaskülit paneli tetkiklerindeantinükleer antikor (ANA) 1/100 pozitif saptandı, anti ds DNA, ANCA, Scl 70, SS-A, SS-B negatif saptandı, protein $C$, protein $S$ normal değerlerdeydi. ANA pozitifliği için romatoloji kliniği görüşü alındı ancak düşük titrede olduğu ve sistemik vaskülit için anlamlı olmadığı belirtildi. Hasta PSSSV ön tanısı ile yapılan MR spektroskopide sol parietal ve bilateral frontoparietal bölgede T2AG imajlarda hiperintens olan, asimetrik, multifokal yerleşimli beyaz cevher lezyonları ve SWAN sekanslarda subkortikal, multifokal serebral mikrohemoraji odakları izlendi (şekil 1). Kranial MR anjiografide (Kr MRA) patoloji saptanmadı (şekil 2).
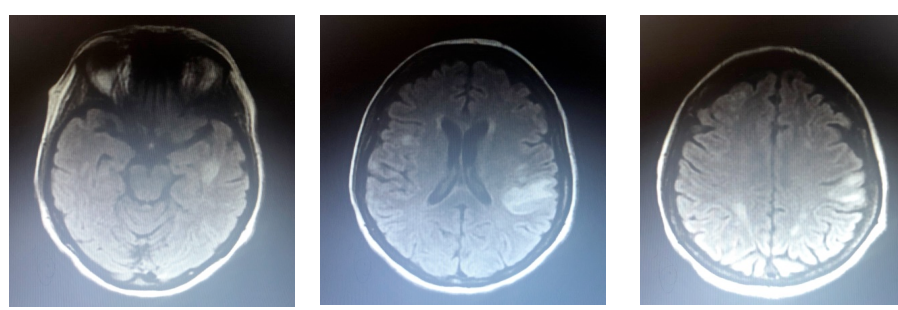

Şekil 1. Kr MRG T2 ağırlıklı kesitlerde sağ frontotemporal, her iki paryetal, sağ frontal bölgede kortikal-subkortikal hiperintens lezyonlar

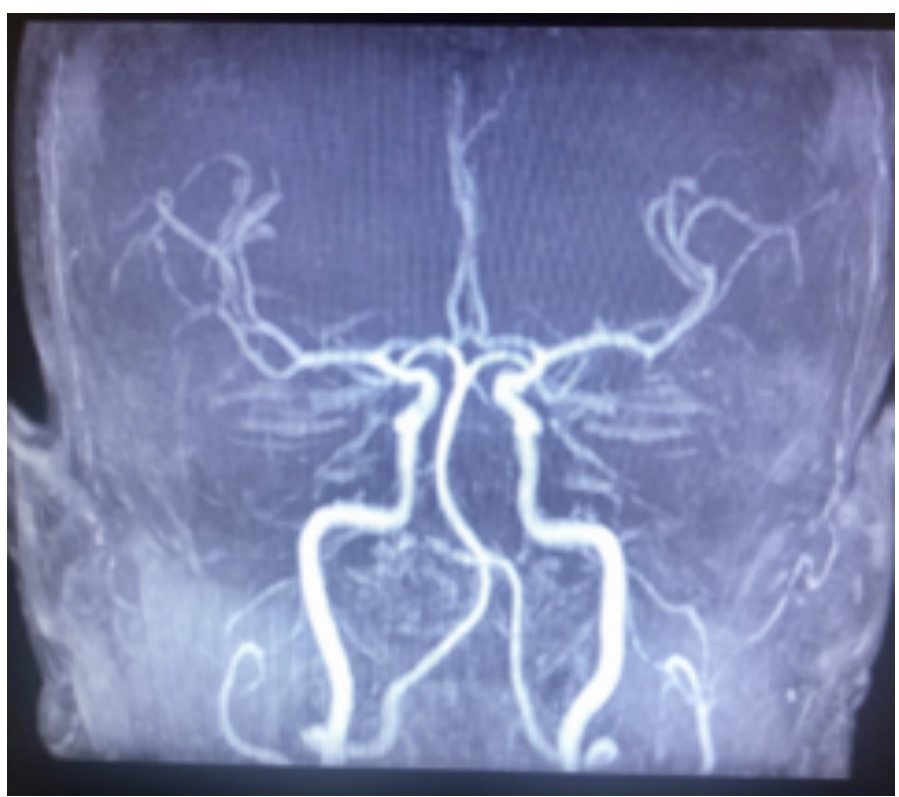

Şekil 2: Kr MRA normal sınırlarda 
Klinik, laboratuar, BOS analiz ve MRG bulguları eşliğinde hastada ön planda PSSSV düşünülerek pulse steroid (1000mg/ gün) tedavisi başlandı. Tedavi sonrası 2. günde hastanın konfüzyonunda ve parezisinde belirgin düzelme gözlendi. Beş gün pulse steroid sonrasında idame oral steroid tedavisine geçildive nörolojik muayenesi tamamen düzelerek taburcu edildi.

\section{Tartışma}

PSSSV oldukça nadir görülen bir hastalıktır. Beyin ve medulla spinalisteki küçük damarları etkiler (2). Etyolojisi tam olarak aydınlatılamamıştır.Klinik bulgular çok çeşitli olabileceği gibi radyolojik bulgular da çok çeşitli ve nonspesifik olabilir (1). Tanıda klinik, laboratuar ve radyolojik bulguların bir arada değerlendirilmesi önemlidir. Tanıda enfeksiyöz patolojiler, sistemik vaskülitler araştırılmalıdır $(1,3)$. Kesin tanı histopatolojik olarak konulur. Ancak tanıda yardımcı olacak görüntüleme yöntemleri ve lomber ponksiyon incelemesi de mevcuttur. Beyin omurilik sıvısında ılımlı lenfosit artışı ve protein seviyelerinde yükselme izlenir (2). Bizim hastamızda da benzer şekilde artmış BOS protein seviyesi mevcuttu.

Vakaların \%93'ünde MRG'de patolojik bulgu saptanmıştır (4). MRG'de multifokal, pek çok damar bölgesinde, tümör benzeri görünümler karşımıza çıkabilir. Kranial MRG'de herhangi bir özellik saptanamayan vakalar da mevcuttur. Bu durumda MR spektroskopi tanıda yardımcı olabilir (1). Bizim vakamızda öncelikle Kranial MRG'de her iki hemisferde multifokal olarak karşımıza çıkan tümör ile karışabilen lezyonlar izlenmiş ve ayırıcı tanıda MR spektroskopiden faydalanılmıştır.

Calabrese ve Mallek, PSSSV tanısı için klinik deneyim ve yayınlanmış çalışmalardan elde edilen kanıtlar temelinde tanı için bazı kriterler önermiştir. Buna göre; aşağıdaki kriterlerin üçünün de karşılanması durumunda kesin tanı konulur (9):

- kapsamlı bir temel değerlendirmenin ardından bilinmeyen kaynaklı bir nörolojik defisitin öyküsü veya klinik bulguları;

- klasik vaskülit özelliklerine sahip serebral anjiyogram veya vaskülit özelliği gösteren bir SSS biyopsi örneği;

- sistemik vaskülit veya anjiyografik veya patolojik özelliklerin sekonder olabileceği başka bir hastalık belirtisinin olmaması.

Genel olarak, anjiyografinin duyarlılığı \% 40 ile\% 90 arasında değişmektedir ve serebral anjiyogramlar \%30 kadar düşük bir özgünlüğe sahiptir (10-13). Anjiyografi ile elde edilen bulgular PSSSV tanısını destekleyebilir. Ancak PSSSV'de hem teknik hem de tanı bağlamında anjiyografinin, altın standart olarak kullanılmasının sınırlamaları vardır. Öncelikli olarak, anjiyografiler, anormal bulgulara neden olan patolojik süreçler ve mekanizmalar hakkında daha fazla bilgi vermeden damar konturlarındaki bölgesel değişiklikler hakkında bilgi sağlar. Ateroskleroz, vazospazm, radyasyon vaskülopatisi, enfeksiyonlar, neoplazi, atriyal miksomalar, nörofibromatoz ve fibromüsküler displazi dahil olmak üzere bir dizi enflamatuar olmayan vaskülopati, PSSSV'dekine benzer anjiyografik bulgulara neden olabilir. Bu nedenle, anjiyografinin özgüllüğü sınırlıdır (8).

Klinik bulgulara eşlik eden histopatolojik tanı mevcut ise "kesin" PSSSV'den bahsetmek mümkündür. Ancak invaziv bir yöntem olması sebebiyle beyin biyopsisi çok tercih edilmemektedir. Klinik bulgulara eşlik eden laboratuvar ve radyolojik bulgular varlığında histopatolojik tanı yapılmamış ise "olası" PSSSV tanısı konulabilir (8). Bizim vakamızda da benzer şekilde klinik, laboratuar, BOS incelemesi ve radyolojik bulgular ile PSSSV tanısı konulup steroid tedavisine başlandı. İnvaziv bir yöntem olan beyin biyopsisi tercih edilmedi.

Ayırıcı tanıda Reversible Serebral Vazokonsriksiyon Sendromu (RSVS) mutlaka araştırılmalıdır. RSVS, kliniğin daha ani başlaması, baş ağrısı bulgularının ön planda olması ve kranial lezyonların gerilemesi ile PSSSV'den ayrılır.Ayırıcı tanıda bir diğer önemli durumsistemik vaskülit ve enfeksiyon ekartasyonudur (14).Bizim vakamızda da klinik bulguların subakut-kronikbir seyirde olması, sistemik vaskülit bulgularının olmaması ve tüm vaskülit sonuçlarının negatif saptanması ve enfeksiyöz panelde hiçbir etkene rastlanmaması PSSSV tanısı için güçlü kanıtlar oluşturmuştur.

Sonuç olarak ilerleyici nörodefisit, konfüzyon-psikoz ve nöbet prezentasyonu ve multifokal tümör benzeri asimetrik, atipik lezyonları olan hastalarda PSSSV mutlaka akılda bulundurulmalıdır. Tanı konulup hızlıca immunsupresan tedavi başlanması hastalığın progresyonu önlemede ve iyi prognoz açısından oldukça önemlidir.

\section{Çıkar çatışması / finansal destek beyanı}

Bu yazıdaki hiçbir yazarın herhangi bir çıkar çatışması yoktur. Yazının herhangi bir finansal desteği yoktur. 


\section{Kaynaklar}

1. Chen SH, Sur S, Sedighim S, Kassi A, Yavagal D, Peterson EC, Starke RM. Utility of diagnostic cerebral angiography in the management of suspected central nervous system vasculitis. J Clin Neurosci 2019;64:98-100.

2. Salvarani C, Brown Jr RD, Calamia KT, Christianson TJ, Weigand SD, Miller DV et al. Primary central nervous system vasculitis: analysis of 101 patients. Ann Neurol 2007;62:442-51

3. Rice CM, Scolding JS. The diagnosis of primary central nervous system vasculitis, Pract Neurol 2019;0:1-7

4. Younger DS, Coyle PK. Central nervous system vasculitis due to infection. Neurol Clin 2019;37: 441-63.

5. Younger DS. Central nervous system vasculitis due to substance abuse. Neurol Clin 2019;37: 425-40.

6. Younger DS. Treatment of vasculitis of the nervous system. Neurol Clin 2019; 37: 399-423.

7. Younger DS. Autoimmune encephalitides. Neurol Clin 2019;37:359-81.

8. Birnbaum J, Hellmann DB. Primary angiitis of the central nervous system. Arch Neurol 2009; 66: 704-09.
9. Calabrese LH, Mallek JA. Primary angiitis of the central nervous system: report of 8 new cases, review of the literature, and proposal for diagnostic criteria. Medicine (Baltimore). 1988;67:20-39.

10. Vollmer TL, Guarnaccia J, Harrington W, Pacia SV, Petroff OAF. Idiopathic granulomatous angiitis of the central nervous system: diagnostic challenges. Arch Neurol 1993; 50: 925-30

11. Salvarani C, Brown RD Jr, Calamia KT et al. Primary central nervous system vasculitis: analysis of 101 patients. Ann Neurol 2007; 62: 442-51.

12. Duna GF, Calabrese LH. Limitations of invasive modalities in the diagnosis of primary angiitis of the central nervous system. J Rheumatol 1995; 22: 662-67.

13. Harris KG, Tran DD, Sickels WJ, Cornell SH, Yuh WT. Diagnosing intracranial vasculitis: the roles of MR and angiography. AJNR Am J Neuroradiol 1994; 15: 317-30.

14. Mehdiyev Z, Öztürk V. Primer Santral Sinir Sisteminin Vasküliti. Turkiye Klinikleri J Neurol-Special Topics 2014;7:72-76 